\title{
sciendo
}

\section{SUBLETHAL COBALT TOXICITY EFFECTS ON RAINBOW TROUT (Oncorhynchus mykiss)}

\author{
Fereshteh Nasri, Saeed Heydarnejad*, Amin Nematollahi
}

Shahrekord University, PO B 115, Shahrekord 88186, Iran

*Corresponding Author, Email: msh@utas.edu.au

\section{ARTICLE INFO}

Received: 3 June 2019

Accepted: 17 October 2019

\section{Keywords:}

Rainbow trout

Heavy metals

Cobalt

Growth

Biochemical parameters

\section{ABSTRACT}

The purpose of this study was to investigate the sublethal Co toxicity on rainbow trout (Oncorhynchus mykiss). Trout were exposed to Co and selected parameters were evaluated at intervals of 1,15 and 30 days. Fish exposed to higher levels of Co grew slower than fish exposed to lower levels of Co. Weight gain, specific growth rate (SGR) decreased linearly with the increase of cobalt in the water. The body condition factor (CF) of fish reared in water with low cobalt concentration decreased substantially but this decrease was not significant for fish exposed to higher cobalt concentration. The values of the feed conversion ratio (FCR) increased in fish exposed to higher levels of Co. Co significantly changed the activity of aspartate aminotransferase (AST) and alanine aminotransferase (ALT) and decreased at day 30 , and in both cases this decrease was more remarkable at day 15 so that the level of AST and ALT reached the control value at day 30. The alkaline phosphatase (ALP) level also showed a remarkable 15day decline. There was a significant increase in glucose $(G)$ concentration in both Co-exposed groups on day 15. However, serum cholesterol (Chl) was significantly reduced on day 15 and increased on day 30; there were no significant differences in both exposed Co-groups. The triglyceride (TG) level also decreased substantially. There was no regular pattern of total protein (TP) in the serum, so that no significant differences were found in the level of TP between low and high-exposed fish. In summary, this study suggests that exposure of essential trace elements such as cobalt may change growth and biochemical parameters, and that measurement of these parameters may be used in toxicological studies to determine the general health status of fish.

Nasri, F., Heydarnejad, S., Nematollahi, A. (2019): Sublethal cobalt toxicity effects on rainbow trout (Oncorhynchus mykiss). Croatian Journal of Fisheries, 77, 243-252. DOI: 10.2478/cjf-2019-0018. 


\section{INTRODUCTION}

The essential heavy metals are interesting subject of research because they also are considered as essential trace elements and they are required at low levels for the function of different biological processes, but at increased levels are toxic to the organism (Zheng et al., 2016). Metals can affect the growth of fish (Saeed, 2000) and most of them are essential for the many physiological processes of fish (Watanabe at al., 1997). Due to the persistence in the aquatic food chain and ability to bio-magnify (Ubaidullah et al., 2004), heavy metal contaminations pose a real threat to aquatic organisms (Javad, 2013).

Cobalt $(\mathrm{Co})$ is essential for fish health as a trace element and part of vitamin $B_{12}$ (Ahilan and Jeyaseelan, 2001). Indeed, insufficient data on the Co toxicity for aquatic organisms have hindered the ecological risk assessment and the development of water quality criteria for Co (De Schamphelaere et al., 2008). Although Co is important for fish nutrition (Davis and Gatlin, 1991), compared to other minerals such as zinc $(\mathrm{Zn})$ or copper $(\mathrm{Cu})$, some articles still find it a trace element in fish nutrition (Blust, 2011). Cobalt toxicity causes haem oxidation and inhibition of inorganic calcium channels in fish gills (Yamatani et al., 1998; Bargagli, 2000). Cobalt is a metal of great concern, which does not naturally occur as a base metal. In separate studies with Cyprinus carpio, Naji et al. (2007) registered 96-hr cobalt $\mathrm{LC}_{50}$ as $327.5 \mathrm{mgL}^{-1}$.

Co intake may have adverse chronic effects at a concentration of $2.0 \mathrm{mg} / \mathrm{l}$ (DWAF, 1996). Fish growth is considered to be a precise, reliable and sensitive endpoint associated with the sublethal exposure of water-borne or dietary metals (Javed and Saeed, 2010). The sublethal effects of metals on aquatic organisms were estimated using fish as a study model (Wong et al., 2001; Javed and Saeed, 2010). The metabolism, breeding, growth and survival of fish are severely affected by exposure to heavy metals (Adhikari et al., 2009). The fish's absorption of heavy metals is potentially toxic and their sublethal exposure could lead to lower growth rates and other physiological and behavioral disorders.

Co is also a cofactor for many enzymes, such as dehydrases, dehydrogenases and transferases (Banerjee and Ragsdale, 2003). Birge et al. (1980) reported a rainbow trout (Oncorhynchus mykiss) $\mathrm{LC}_{50}$ value of $490 \mu \mathrm{g} / \mathrm{l}$ with 28-day Co exposure endpoints. Co-dose $(0.1-5 \mathrm{~g} \mathrm{Co} / \mathrm{kg})$ is toxic to rainbow trout, resulting in digestive tract hemorrhage and changes in white blood cells (Watanabe et al., 1997). Fathi and Al-Omair (2006) reported that higher cobalt doses had a strong impact on growth parameters of fish. On the other hand, carp (Cyprinus carpio) had reduced weight gain and specific growth rates without adequate dietary supplementation with Co (Mukherjee and Kaviraj, 2009).

Biochemical indices are parameters of great importance for assessing the physiological status of fish. Their changes depend on the species of fish, age, sexual maturity cycle of spawners and diseases (Whethertley and Cill, 1987; Zhiteneva et al., 1989; Golovina, 1996; Luskova, 1997). As in warm-blooded animals, changes in the blood parameters of fish can be used to determine and confirm organ or tissue dysfunction or injury. These parameters, however, are more related in the fish to the response of the entire organism, i.e. to the effect on fish survival, reproduction and growth (Golovina, 1996). Fish growth rates are highly variable and are highly sensitive to environmental factors. As a result, growth rate measurements provide information on fish performance (Zhiteneva et al., 1989).

Fish growth depends on water's physiochemical parameters and usually decreases in contaminated waters (Whethertley and Cill, 1987). Physiological or behavioral stress during toxicant exposure reduces growth (Alabater and Loyd, 1980). The indices of blood chemistry, including enzymes, nutrients, metabolites, waste products and inorganic ions, were used to detect cell damage and metal response. Many studies have shown that certain metals can either increase or decrease G, TP, osmolality, $\mathrm{Chl}$, TG and enzymes in the blood depending on the type of metal, fish species, water quality and exposure length (Dixon and Sprague, 1981; Authman et al., 2013; Authman et al., 2015; Dhankumar et al., 2015; Jitarm et al., 2015). Many of these parameters react quickly as part of a non-specific stress response after exposure to sublethal metal concentrations. The response is temporary if the stressor can be compensated by the animal or if the stressor is removed (Fazio et al., 2014). Changes in the activity of serum enzymes are used as indicators of tissue injury, environmental stress or illness. The rate of increase in serum enzyme activity depends on the concentration of an enzyme in cells, the rate of injuryinduced leakage and the rate of serum clearance of the enzyme (Zikic et al., 2001). Serum enzymes such as ALP, ALT and AST are considered important serum markers for investigating animal health concerns. ALP is a hydrolase enzyme that removes phosphate groups from a variety of molecules, including nucleotides, proteins, alkaloids or dephosphorylation. It is a polyfunctional enzyme that acts in alkaline $\mathrm{pH}$ and plays a major role in the mineralization of aquatic animal skeletons (Lan et al., 1995; Levesque et al., 2003). Furthermore, ALT and AST are the most important enzymes involved in the metabolism of proteins and amino acids (Lan et al., 1995). Co toxicity to fish appears to be relatively low compared to the effects of other metal ions, particularly during short-term exposures. Lethal level for Co was reported to be ILL for $50 \%$ mortality in the concentration of $346 \mu \mathrm{g} \mathrm{I}^{-1}$. The aim of this study was therefore to investigate the sublethal Co toxicity effects (10 and $30 \mu \mathrm{g} / \mathrm{l})$ on growth and biochemical parameters including enzymes such as ALP, AST and ALT, G, TG, Chl and TP in rainbow trout (Oncorhynchus mykiss). 


\section{MATERIALS AND METHODS}

\section{Fish holding conditions and acclimation}

Rainbow trout (Oncorhynchus mykiss), corresponding to size $(17.5 \pm 0.3 \mathrm{~g} ; 11.4 \pm 0.2 \mathrm{~cm})$, were transferred to the laboratory. 20 fish were kept under a natural photoperiod in continuously aerated tanks (500 I) (12 hours light 12 hours dark). Experimental water physicochemical characteristics (dechlorinated and filtered freshwater) were as follows: temperature $9.0 \pm 1.0^{\circ} \mathrm{C}, \mathrm{pH} 7.8 \pm 0.2$, concentration of dissolved oxygen, $7.8-8.3 \mathrm{mg} / \mathrm{l}$, total hardness as $\mathrm{CaCO}_{3} 104.2 \mathrm{mg} / \mathrm{l}$, total alkalinity as $\mathrm{CaCO}_{3}$ $78.8 \mathrm{mg} / \mathrm{l}$ and total dissolved solids $173 \mathrm{mg} / \mathrm{l}$ (Table 1). All tanks were monitored daily for temperature, DO (dissolved oxygen), TDS (total dissolved solids) and $\mathrm{pH}$. Hardness and alkalinity were measured by titrimetric methods four times a week in a subset of tanks. The fish were hand-fed twice a day at random with commercial dry pellets during an acclimatization period of 2 weeks. The feed consisted of $40.69 \pm 0.3 \%$ crude protein, $53.7 \pm 0.18 \%$ crude lipid, $25.59 \pm 0.11 \%$ ash and $11.13 \pm 0.5 \%$ humidity. Fish were fed for 30 days at a feeding rate of $2 \%$ of body weight a day. Any fish showing abnormal behavior was removed from the tanks immediately.

Table 1. Water quality parameters, cations, anions, and background metals in acclimation (Mean \pm SD)

\begin{tabular}{|c|c|}
\hline Parameters & Acclimation water \\
\hline Temperature $\left({ }^{\circ} \mathrm{C}\right)$ & $9 \pm 1{ }^{\circ} \mathrm{C}$ \\
\hline $\mathrm{pH}$ & $7.8 \pm 0.2$ \\
\hline Dissolved oxygen (mg/L) & $7.8-8.3$ \\
\hline Total Hardness (mg/L as $\mathrm{CaCO}_{3}$ ) & 104.2 \\
\hline Total alkalinity (mg/L as $\mathrm{CaCO}_{3}$ ) & 78.8 \\
\hline Total dissolved solids (mg/L) & 173 \\
\hline Sodium (mg/L) & 5.0 \\
\hline Calcium (mg/L) & 31.0 \\
\hline Potassium (mg/L) & 0.5 \\
\hline Magnesium (mg/L) & 6.4 \\
\hline $\mathrm{Cl}(\mathrm{mg} / \mathrm{L})$ & 11.3 \\
\hline $\mathrm{NH}_{3}(\mathrm{mg} / \mathrm{L})$ & 0.05 \\
\hline $\mathrm{SO}_{4}^{-2}(\mathrm{mg} / \mathrm{L})$ & 15.0 \\
\hline $\mathrm{PO}_{4}^{-3}(\mathrm{mg} / \mathrm{L})$ & 0.05 \\
\hline Copper $(\mu \mathrm{g} / \mathrm{L})$ & 0.63 \\
\hline Cadmium ( $\mu \mathrm{g} / \mathrm{L})$ & 0.57 \\
\hline Cobalt $(\mu \mathrm{g} / \mathrm{L})$ & 0.264 \\
\hline
\end{tabular}

\section{Exposure system}

Active groups of 20 fish were transferred randomly to tanks with continuous aeration of 160 I of polyethylene. With three replicas, the fish were exposed to: (i) control: nominally zero cobalt [actual measured 'in-tank' value: $91.37 \mu \mathrm{g} / \mathrm{l}]$, (ii) low Co $[10 \mu \mathrm{g} / \mathrm{l}]$ and (iii) high Co [30 $\mathrm{\mu g} / \mathrm{l}]$ for 1,15 and 30 days. Co was added with three replicates as $\mathrm{CoCl}_{2} \cdot 6 \mathrm{H}_{2} \mathrm{O}$ (Merck, Germany). Water has been changed every 2 days to minimize metal loss and maintain metal concentration. During the experimental period, the water quality parameters mentioned were evaluated during the collection days. Calculated growth performance as follows:

Condition Factor (CF) $=100$ Weight $(\mathrm{g}) /$ Length $^{3}(\mathrm{~cm})$

Specific Growth Rate (as percentage of body weight gain per day) $=100 \times$ [in final weight $(\mathrm{g})-$ in initial weight (g)] / time (days)

Feed conversion ratio $(F C R)=$ feed intake/weight gain Weight Gain Percentage (WGP) $=[$ final weight $(\mathrm{g})-$ initial weight (g)] / initial weight (g)

\section{Sampling and biochemical processing}

Before sampling, the fish were fasting for 24 hours. On days 1,15 and 30 , fish were removed from each tank and anesthetized using clove oil $(25 \mathrm{mg} / \mathrm{l})$. The weight and length of the individual fish were measured before and at the end of the experiment. Fish blood samples (not pooled) were obtained from caudal veins using a hypodermic syringe. Blood samples were kept in a refrigerator for 4 hours immediately. Serum was separated from cells by centrifuging entire blood $\left(10 \mathrm{~min}, 4000 \mathrm{~g}, 4^{\circ} \mathrm{C}\right)$ and stored at $-48^{\circ} \mathrm{C}$ until experimental testing. A biochemical analyzer Hitachi 911 (Japan) was used to measure the levels of AL, AST and ALP with concentrations of G, TG, Chl and TP in the serum.

\section{Statistical analysis}

Initially, the raw data were checked by Kolmogorov Smirnov tests for normal distribution. A means \pm standard means error (SEM) was expressed in all values. Analyzing differences between control and different sampling times in each exposure group and growth parameters was tested through one - way variance analysis (ANOVA). The multiple range test of the post hoc Duncan was used among SPSS 14 treatment means. Significance at $\mathrm{P}<0.05$ has been determined.

\section{RESULTS}

Qualitative findings of fish feeding behavior in the current study revealed that fish in Co-exposed groups were not aggressively fed, and a significant decrease in feeding activity and loss of appetite was observed in high Co exposure. 


\section{Growth}

Table 2 shows the effects of sublethal Co exposure on 0 . mykiss growth. There were no mortality during the experiment. Weight gain and SGR decreased linearly as Co levels increased in water. The body CF of fish grown in water with low Co concentration also decreased significantly $(p<0.05)$, but this decrease was not significant for fish exposed to higher Co concentrations. Fish exposure to various concentrations of Co in water $(p<0.05)$ significantly reduced feed consumption compared to the control - direct correlation with the concentration of cobalt in water. The values of the FCR only increased for fish exposed to higher levels of Co.

Table 2. Growth performance of rainbow trout (Oncorhynchus mykiss) in the control, low exposed $(10 \mu \mathrm{g} / \mathrm{L})$ and high exposed $(30 \mu \mathrm{g} / \mathrm{L})$ cobalt over the experimental period of 30 days

\begin{tabular}{cccc}
\hline $\begin{array}{l}\text { Parameters/ } \\
\text { groups }\end{array}$ & Control & Low Co & High Co \\
\hline MWi & $17.63 \pm 0.38$ & $17.88 \pm 0.33$ & $17.53 \pm 0.36$ \\
MWf & $47.05 \pm 1.75^{\mathrm{a}}$ & $44.20 \pm 2.99^{\mathrm{b}}$ & $29.81 \pm 3.0^{\mathrm{b}}$ \\
MBLi & $11.63 \pm 0.09$ & $11.6 \pm 0.05$ & $11.5 \pm 0.10$ \\
MBLf & $16.07 \pm 0.18^{\mathrm{a}}$ & $15.93 \pm 0.29^{\mathrm{a}}$ & $13.76 \pm 0.23^{\mathrm{b}}$ \\
Cfi & $1.12 \pm 0.01$ & $1.12 \pm 0.16$ & $1.10 \pm 0.01$ \\
CFf & $1.13 \pm 0.02^{\mathrm{a}}$ & $1.09 \pm 0.01^{\mathrm{b}}$ & $1.13 \pm 0.05^{\mathrm{a}}$ \\
SGR & $3.27 \pm 0.67^{\mathrm{a}}$ & $3.01 \pm 0.15^{\mathrm{a}}$ & $1.72 \pm 0.24^{\mathrm{b}}$ \\
WGP & $166.87 \pm 10.65^{\mathrm{a}}$ & $147.20 \pm 13.33^{\mathrm{b}}$ & $70.05 \pm 1.32^{\mathrm{c}}$ \\
FCR & $0.67 \pm 0.17^{\mathrm{b}}$ & $0.67 \pm 0.18^{\mathrm{b}}$ & $1.13 \pm 0.05^{\mathrm{a}}$ \\
\hline \hline
\end{tabular}

MWi, initial mean weight (g); MWf, final mean weight (g); MBLi, initial mean body length $(\mathrm{cm})$; MBLf, final mean body length (cm); CFi: initial condition factor; CFf: final condition factor; SGR: specific growth rate; WGP: weight gain percentage; FCR: feed conversion ratio. Significant differences between values in columns are indicated with letters $(p<0.05)$; values in columns with the same letters are not significantly different

\section{Serum enzymes}

Figures 1 and 2 show changes in rainbow trout biochemical parameters during sublethal Co exposure. Co significantly changed the activity of both AST and ALT and decreased at day 30 (Fig. 1). In both cases, this reduction was more significant on day 15 so that the AST and ALT levels reached the control value on day 30 . A similar pattern for the ALP activity was observed. When the fish were exposed to both sublethal concentrations of $\mathrm{Co}$, the level of ALP decreased significantly in 15 days and then returned to normal on day 30 .
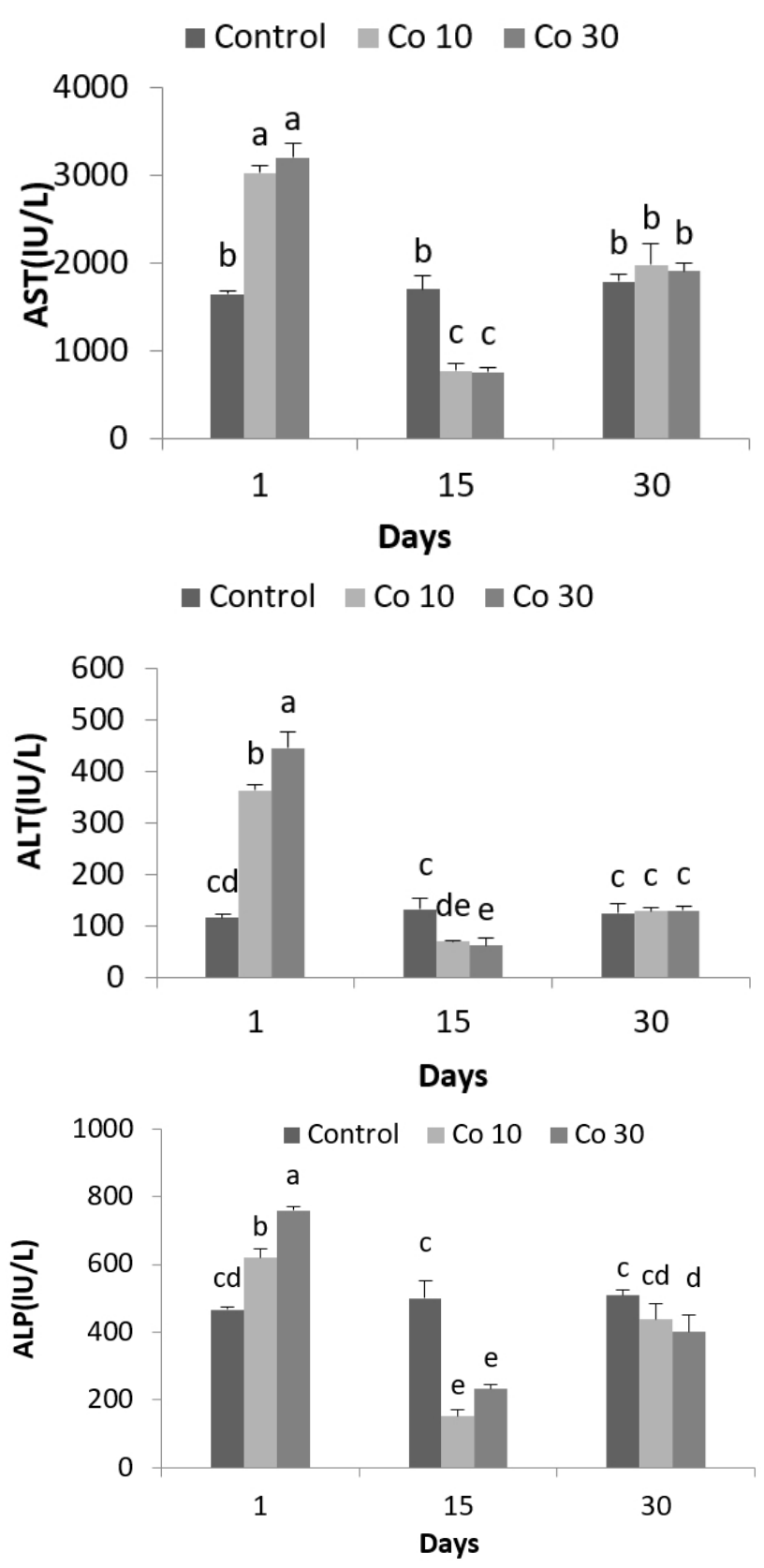

Fig 1. Effects of different sublethal cobalt concentrations on serum enzymes activities. (upper) Serum aspartate transaminase (AST), (middle) Serum alanine transaminase (ALT), (lower) Serum alkaline phosphatase (ALP) in Oncorhynchus mykiss exposed to cobalt. Data are expressed as mean \pm standard error (SE). Means with different letters are significantly different from each other $(p<0.05)$

\section{Serum biochemical parameters}

The concentration of $\mathrm{G}$ increased significantly in both Coexposed groups on day 15 , especially in the concentration of $30 \mu \mathrm{g} / \mathrm{L}$ Co and increased to $190 \pm 8.18 \mathrm{mg} / \mathrm{dl}$ compared to $30.67 \pm 2.96 \mathrm{mg} / \mathrm{dl}$ in the control group. This $\mathrm{G}$ elevation was transient and dropped to $56.67 \pm 2.67 \mathrm{mg} / \mathrm{dl}$ within 


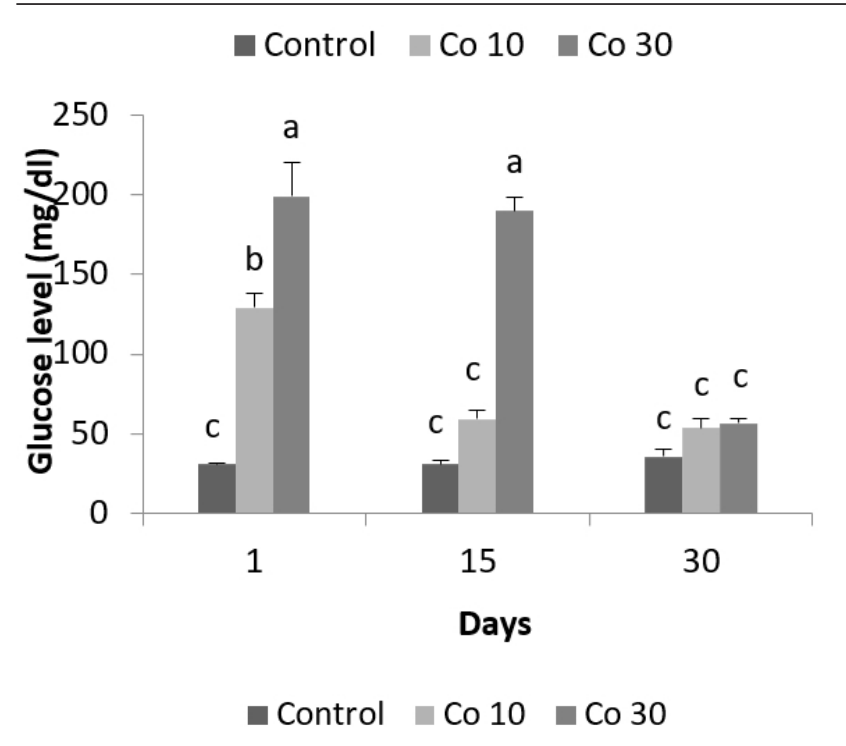

- Control $\backsim$ Co $10 \quad$ Co 30
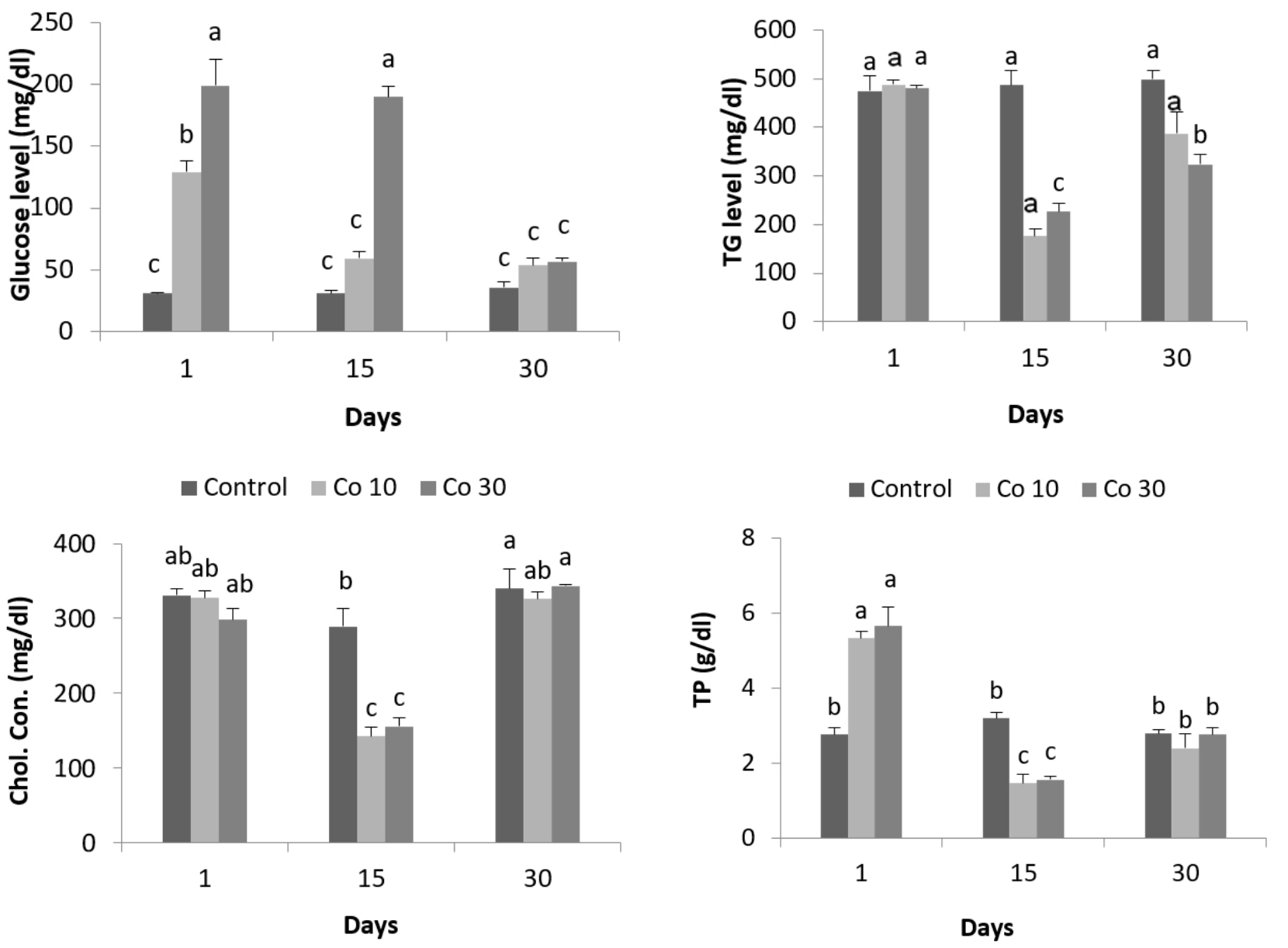

Fig 2. Effects of different sublethal cobalt concentrations on biochemical parameters. (upper- left) Serum glucose level; (upper right) Serum triglyceride (TG) level; (lower-left) Serum cholesterol concentration (Chol. Conc.); (lower-right) Serum total protein (TP) level in Oncorhynchus mykiss exposed to cobalt. Data are expressed as mean \pm standard error (SE). Means with different letters are significantly different from each other $(p<0.05)$. Values with the same letters are not significantly different.

30 days of high exposure to Co. However, there was no significant difference between the high $(30 \mu \mathrm{g} / \mathrm{L})$ and low (10 $\mu \mathrm{g} / \mathrm{L}$ ) dose groups in serum $\mathrm{G}$ levels (Fig. 2). At day 15 of exposure to various concentrations of $\mathrm{Co}$, TG levels decreased significantly to their minimum value and reached $177 \pm 13.32 \mathrm{mg} / \mathrm{dl}$ in low exposure groups and $226.33 \pm 29.63$ in high exposure groups of Co compared to $486.67 \pm 29.36 \mathrm{mg} / \mathrm{dl}$ in the control groups. This significant depression followed by a rapid rise in 30 days, but TG levels were still lower in both exposure groups than control levels (Fig. 2).

On the first day of the experiment, serum $\mathrm{Chl}$ did not show any significant difference between the Co exposed groups and the control group. However, on day 15, serum Chl decreased significantly, reaching $142.67 \pm 11.61 \mathrm{mg} / \mathrm{dl}$ in low exposure and $155.67 \pm 12.14 \mathrm{mg} / \mathrm{dl}$ in high exposure Co-groups compared to $289.33 \pm 24.26 \mathrm{mg} / \mathrm{dl}$ in the control group. Although the level of serum Chl in low (121.29\%) and high (121.29\%) exposed Co-groups increased by day
30, this increase showed no significant difference in both exposed Co-groups. This finding suggests that there is no dose-dependent effect of Co on Chl level. Total serum protein did not show a regular pattern so that after a sharp reduction in 15 days, it increased rapidly to $2.4 \pm 0.4$ $\mathrm{g} / \mathrm{dl}$ (low dose) and $2.767 \pm 0.18 \mathrm{~g} / \mathrm{dl}$ (high dose) compared to $2.8 \pm 0.1 \mathrm{~g} / \mathrm{dl}$ in the control group on day 30 (Fig. 2). In any case, however, there were no significant differences between low and high-exposed fish in the level of total protein.

\section{DISCUSSION}

\section{Growth during chronic Co exposure}

Fish exposed to higher levels of Co grew slower than fish exposed to lower levels of Co (Table 2). This shows the dose-dependent growth of the test fish. The 
growth performance of both treated and non-treated experimental group varied considerably over the 30-day experimental period. Many studies have shown a lower rate of growth in fish exposed to metal mixtures due to changes in enzyme capacity (Lan et al., 1995; Zikic et al., 2001) and changes in food base in contaminated waters in some situations (Levesque et al., 2003). In this study, growth parameters such as condition factor or SGR and total weight gain were lower after exposure to high-dose Co. Due to exposure to Co, metabolic demands associated with metal detoxification are due to reduced production. Such high metabolic demands divert resources from normal growth processes (Health, 1995). The results of this study were supported by the results of Hayat et al. (2007) who recorded significantly variable growth patterns in major Indian carps (Catla catla, Labeo rohita and Cirrhina mrigala) exposed to sub-lethal heavy metal concentrations for 90 days. Furthermore, Abbas and Javed (2016) exposed Labeo rohita to sublethal Co and found a decrease in growth parameters. The decreased growth observed in this study may be explained by impaired fish feeding activity (De Schamphelaere et al., 2008). Indeed, qualitative observations of fish feeding behavior indicated that the feeding of fish exposed to high levels of Co $(30 \mu \mathrm{g} / \mathrm{L})$ was significantly inhibited during this period, as feeding inhibition is a well-known response of aquatic organisms to metal exposure (Allen et al., 1995). For example, after 48-hour exposure to heavy metals, Crichton et al. (2004) reported feeding inhibition of Lymnaea peregra. However, toxicant inhibition mechanisms of feeding are not well understood.

\section{Serum enzymes and parameters}

Stress conditions in fish caused by heavy metals increase energy requirements mainly from carbohydrates such as $G$ and non-carbohydrate sources such as proteins and lipids through gluconeogenic enzymes such as AST and ALT (Tuncsoya et al., 2016). Significant responses in biochemical parameters are usually followed by a similar pattern: an early elevation or depression is followed by return to baseline values in chronic heavy metal exposures (Detholff et al., 1999). This pattern suggests gradual acclimatization to the toxicant. In our experiment, the same trend was also found for sera levels of AST and ALT in O. mykiss and caused the linear decrease of AST and ALT over the period of 30 days. It was obvious that higher concentrations of Co have a more significant effect on fish.

Chen et al. (2004) also found that tilapia serum AST and ALT values were significantly reduced during copper exposure. Zinc, on the other hand, increased the activities of sera AST and ALT in O. niloticus in short and long periods of exposure (Younis et al., 2012). The contrast between our studies and others on $\mathrm{Zn}$ may be due to species, stage of life history, sex, age of fish and temperature, hardness and water $\mathrm{pH}$ (Abbas et al., 2007). The Co toxicity mechanism is not well understood, but some of the effects of Co are associated with its high affinity to sulfhydryl groups, which can inhibit critical enzymes (Hille, 1992). Nevertheless, Waiwood and Beamish (1978) presented evidence to suggest that exposure to $\mathrm{Cu}$ influences the basal metabolic rate of salmonids, which could limit growth through decreased efficiency of energy utilization coupled with increased metabolic maintenance costs.

ALP is a bloodstream enzyme that helps break down proteins in the body. It acts as transphosphorylase at alkaline $\mathrm{pH}$ and plays an important role in the mineralization of the aquatic animal skeleton and in the activities of membrane transport (Bernet et al., 2001). An increase in the ALP on the first day of this study could be attributed to the enzyme's functional activity as an adaptive response to mitigate metal toxicity, although it was reduced on day 15. Fish (Salmo trutta) living in naturally contaminated water also had reduced ALP activity (Oner et al., 2008). In the current study, the decrease in ALP activity of Coexposed fish may result from disruption of the membrane transport system, while tissue damage may be correlated with the increase in activity (Abdel-Hameid, 2011).

The present study showed a significant increase in blood G levels in Co-exposed fish after 30 days of exposure. Similarly, common carp blood showed a significant increase in $G$ during 32 days of heavy metal exposure, which may have resulted in hyperglycemia due to vulnerable stress caused by heavy metals (Vinodhini and Narayanan, 2008). Blood $G$ changes are generally a good indicator of metal stress in fish (Bedii and Kenan, 2005) and changes in G levels may be associated with kidney damage, liver damage and lack of nutrition (Pratap and Wenderlaar Bonga, 1990). This study showed that $G$ levels increased after the first 15 days. In 15-d Co-exposed fish, the highest increase in $\mathrm{G}$ levels occurred $(190 \pm 8.18 \mathrm{mg} / \mathrm{L})$ when compared to the control (30.67 $\pm 2.96 \mathrm{mg} / \mathrm{L}$; Fig. 2). Likewise, Co administration was shown to induce hyperglycemia in Channa punctatus (Khanna and Gill, 1975). The increase in blood $\mathrm{G}$ levels is a response to the rise in glycogenolysis or gluconeogenesis (Bolawa and Gbenle, 2013). This may result from glycogenolysis (the release of $\mathrm{G}$ into the blood from energy resources stored as glycogen in muscles and liver) initiated by hormones (cortisol and catecholamines) when the organism was in adverse condition. The reduced $G$ level at the end of exposure probably reflected the exhaustion of the organism's energy reserves and the impairment of the fish's capacity to restore them and the acclimatized condition (Ln and Vosyliene, 1999).

The concentration of TGs is important for the evaluation of lipid metabolism and may result in higher levels due to liver and kidney failure causing $\mathrm{Chl}$ release into the bloodstream (Oner et al., 2008). TGs primarily function in the provision of cellular energy and can be used as a nutritional status indicator. The present study showed a 15-day reduction in serum TG concentrations and then a 30-day increase. It does not seem to be consistent 
in the literature with serum TG concentrations with heavy metal exposed fish. No changes in the serum TG concentrations of fish were observed when Oreochromis niloticus was exposed to $\mathrm{Zn}$. Furthermore, Lévesque et al. (2003) showed that TG levels in Perca flavescens exposed to $\mathrm{Zn}$ sublethal levels varied according to seasons. These variations in serum TG concentrations may be due to differences in exposure, lipid metabolism and impairment of glycogen storage in different fish species.

$\mathrm{Chl}$ value is known to be associated with lipid metabolism and liver and kidney functions (Yan and Chen, 2003). In this study, the concentrations of $\mathrm{Chl}$ in the serum of Coexposed fish were generally increased, compared to the control value, and the highest increase was in 30-d Coexposed fish. The increase in $\mathrm{Chl}$ content suggests the possible involvement of the amino acid carbon skeleton and acetyl CoA in the biosynthesis of $\mathrm{Chl}$ (Aride et al., 2007; John, 2007), which could have given body weight gain and normal metabolism to carbohydrates. Furthermore, lipid homeostasis is one of the main functions of the liver, so any change in the concentration of serum $\mathrm{Chl}$ can be a clear indication of liver and/or kidney dysfunction. The elevation of serum $\mathrm{Chl}$ concentrations in Co-exposed fish is parallel to findings reported in other heavy metals such as Oreochromis niloticus exposure to $\mathrm{Cu}$ (Mutlu et al., 2015) and/or Clarias gariepinus exposure to Zn (Tuncsoya et al., 2016). This increase in Chl concentrations is due, in particular, to the membranes, to the dangerous effects of cobalt on the cell membrane. Higher Chl levels are therefore good indicators of fish environmental stress.

Changes in TP can be caused by liver damage, reduced absorption and protein loss, and can therefore be a good indication of fish's health (Oner et al., 2008). In fact, TP is used to evaluate protein metabolism; with nephritic syndrome and liver disorder low concentrations may occur (John, 2007). Although the current study showed a significant reduction in TP within 15 days, the value of TP increased again and reached the control fish value at day 30. By contrast, the total protein concentration in the $\mathrm{Cu}$-exposed Nile Tilapia Oreochromis niloticus serum after three periods was significantly lower than that of the control fish (Mutlu et al., 2015). The researchers correlated this with variations in sensitivity and species concentration.

\section{CONCLUSION}

This study suggests that exposure of essential trace elements such as Co can be harmful to fish even at low concentrations, as indicated in changes of growth and biochemical parameters. Thus, in toxicological studies, these parameters can be used to find the general health status of fish.

\section{ACKNOWLEDGMENTS}

The authors want to thank the University of Shahrekord for allowing us to carry out this study.

\section{SAŽETAK}

\section{UTJECAJ SUBLETALNE TOKSIČNOSTI KOBALTA NA KALIFORNIJSKU PASTRVU (Oncorhynchus mykiss)}

Svrha istraživanja je bila ispitati subletalnu toksičnost kobalta (Co) kod kalifornijske pastrve (Oncorhynchus mykiss). Ribe su bile izložene Co i odabrani pokazatelji su procijenjeni u intervalima od 1, 15 i 30 dana. Pastrve izložene višim razinama Co imale su sporiji rast od riba izloženih nižim razinama Co. Prirast mase (WG) i specifična stopa rasta (SGR) linearno se smanjivala $S$ porastom kobalta u vodi. Kondicijski faktor riba izloženoj nižoj koncentraciji Co bio je značajno smanjen. Vrijednosti konverzije hrane (FCR) su se povećale kod riba izloženoj višim koncentracijama kobalta. Co je značajno promijenio aktivnost enzima AST i ALT te se smanjio tijekom 30 dana. Razina alkalne fosfataze (ALP) također je pokazala značajan pad ali već tijekom 15 dana. Došlo je i do značajnog povećanja koncentracije glukoze (G) u obje skupine izložene Co 15.ti dan. Međutim, kolesterol u serumu (Chl) je bio značajno smanjen $15.0 g$ dana, a povećao se tijekom 30 dana istraživanja. Razina triglicerida (TG) također se značajno smanjila a značajne razlike u razini ukupnih proteina (TP) nisu utvrđene između riba izložene niskoj i visokoj koncentraciji Co. Istraživanjem se utvrdilo da izlaganje esencijalnim elemenatima u tragovima kao što je kobalt može utjecati na rast i biokemijske parametre pastrve. Mjerenje navedenih pokazatelja u istraživanju se može upotrijebiti u toksikološkim analizama za utvrđivanje općeg zdravstvenog stanja ribe.

Ključne riječi: kalifornijska pastrva, teški metali, kobalt, rast, biokemijski pokazatelji

\section{REFERENCES}

Abbas, S., Javed, M. (2016): Growth performance of Labeo rohita under chronic dual exposure of water-borne and dietary cobalt. Pakistan Journal of Zoology, 48, 257264.

Abdel-Hameid, N.A.H. (2011): Effect of starving and feeding on some haematological and physiological responses of the Nile catfish, Clarias gariepinus exposed to copper at extreme seasons. Fish Physiology and Biochemistry 37, 875-884. 
Adhikari, S., Ghosh, L., Giri, B.S., Ayyappan, S. (2009): Bioaccumulation of some heavy metals in tilapia fish relevant to their concentration in water and sediment of Wadi Hanifah, Saudi Arabia. African Journal of Biotechnology, 10, 254-257.

Ahilan, B., Jeyaseelan, M.J.P. (2001): Effect of cobalt chloride and vitamin B12 on the growth and gonadal maturation of goldfish, Carassius auratus. Indian Journal of Fish, 48, 369-374.

Alabater, J.S., Loyd, R. (1980): Water Quality Criteria for Freshwater Fish. 297, Boston, London.

Allen, Y., Calow, P., Baird, D. J. (1995): A mechanistic model of contaminant-induced feeding inhibitions in Daphnia magna. Environmental and Toxicological Chemistry, 14, 1625-1630.

Aride, P. H. R., Roubach, R., Val, A. L. (2007): Tolerance response of tambaqui Colossoma macropomum (Cuvier) to water pH. Aquaculture Research, 38, 588594.

Authman, M. M. M., Abbas, H. H., Abas, W. T. (2013): niloticus fish in relation to human health. Environmental Monitoring and Assessment, 185, 891-005.

Authman, M.N., Zaki, M.S., Khallaf, E.L., Abbas, H.H. (2015): Use of fish as bio-indicator of the effects of heavy metals pollution. Journal of Aquaculture and Research Development, 6, 1-13.

Bargagli, R. (2000): Trace metals in Antarctica related to climate changes and increasing human impact. Rev. Environ. Contam.Toxicol. 166, 129-173.

Banerjee, R., Ragsdale, S. W. (2003): The many faces of vitamin B12: catalysis by cobalamin dependent enzymes. Annal Review of Biochemistry, 72, 209-24.

Bedii, C., Kenan, E. (2005): The effects of Cadmium on levels of glucose in serum and glycogen reserves in the liver and muscle tissues of Cyprinus carpio L. Turkish Journal of Veterinary and Animal Science, 29, 113-117.

Bernet, D., Schmidt, H., Wahli, T., Burkhardt-Holm, P. (2001): Effluent from a sewage treatment works causes changes in serum chemistry of brown trout (Salmo trutta L.). Ecotoxicological and Environmental Safety, 48, 140-147.

Birge, W. J., Black, J. A., Westerman, A. G., Hudson, J. E. (1980): Aquatic toxicity tests on inorganic elements occurring in oil shale. In Sampling, Analysis and Quality Assurance (Gale C, Ed), 519-553. Technical Information Service, Springfield, VA.

Blust, R. (2011): Cobalt. Homeostasis and toxicology of essential metals. Fish Physiology, 31, 291-326.

Bolawa, O. E., Gbenle, G. O. (2013): Effect of consumption of heavy metals contaminated fish (Tilapia oreochromis) on metabolic parameters in rabbits. International Journal of Applied Biology and Pharmaceutical Technology, 4, 317-321.

Chen, C. Y., Wooster, G. A., Bowser, P. R. (2004): Comparative blood chemistry and histopathology of tilapia infected with Vibrio vulnificus or streptococcus iniae or exposed to carbon tetrachloride, gentamicin, or copper sulphate. Aquaculture, 239, 421-443.

Crichton, C. A., Conrad, A. U., Baird, D. J. (2004): Assessing stream grazer response to stress: Apostexposure feeding bioassay using the freshwater snail Lymnaea peregra (Muller). Bulletin of Environmental Contamination and Toxicology, 72, 564-570.

Data, S., Ghosh, D., Saha, D.R., Bhattacharaya, S., Mazumder, S. (2009): Chronic exposure to low concentration of arsenic is immunotoxic to fish: Role of head kidney macrophages as biomarkers of arsenic toxicity to Clarias batrachus. Aquatic Toxicology, 92, 86-94.

Davis, D.A., Gatlin, D. M. (1991): Dietary mineral requirements of fish and shrimp. In Proceedings of the Aquaculture Feed Processing and Nutrition Workshop, Thailand and Indonesia (Akiyama DM, Tan R Eds). pp 49-46, American Soybean Association, Singapore.

De Schamphelaere, K. A. C., Koene, J. M., Heijerick, D. G., Janssen, C. R. (2008): Reduction of growth and haemolymph Ca levels in the freshwater snail Lymnaea stagnalis chronically exposed to cobalt. Ecotoxicological and Environment Safety, 71, 65-71.

Detholff, G. M., Schlenk, D., Hamm, J. T., Bailey, H. C. (1999): Alterations in physiological parameters of rainbow trout (Oncorhynchus mykiss) with exposure to copper and copper/zinc mixtures. Ecotoxicological and Environ Safety, 42, 253-264.

Dhanakumar, S., Solaraj, G., Mohanraj, R. (2015): Heavy metal partitioning in sediments and bioaccumulation in commercial fish species of three major reservoirs of river Cauvery delta region, India. Ecotoxicological and Environmental Safety, 113, 145-151.

Dixon, D. G., Sprague, J. B. (1981): Copper bioaccumulation and hepatoprotein synthesis during acclimation to copper by juvenile rainbow trout. Aquatic Toxicology, $1,69-81$.

DWAF (1996): Department of water affairs and forestry. South African Water Quality Guidelines, DWAF, Pretoria 8, 11-15.

Fathi, A.A., Al-Omair, M.A. (2006): Effects of pH on toxicity of cadmium, cobalt and copper to Scenedesmus bijuga. Protistology, 4, 221-226.

Fazio, F., Piccione, G., Tribulato, K., Ferrantelli, V., Giangrosso, G., Arfuso, F. Faggio C. (2014): Bioaccumulation of heavy metals in blood and tissue of striped mullet in two Italian Lakes. Journal of Aquatic Animal Health, 26, 278-284.

Golovina, N.A. (1996): Morphofunctional characteristics of the blood of fish as objects of aquaculture. $53 \mathrm{pp}$ (in Russian). Doctoral thesis, Moscow.

Hayat, S., Javed, M., Razzaq, S. (2007): Growth performance of metal stressed major carps viz., Catla catla, Labeo rohita and Cirrhina mrigala reared under semi-intensive culture system. Pakistan Veterinary Journal, 27, 8-12.

Hasan, J. A., Marr, J. C. A., Lipton, A., Cacela, D. L., Bergman, B. L. (1999): Differences in neurobehavioral 
responses of chinook salmon (Oncorynchus tshawytscha) and rainbow trout (Oncorhynchus mykiss) exposed to copper and cobalt: Behavioral avoidance. Environmental Toxicological Chemistry, 18, 1972-1978. Health, A.G. (1995): Water Pollution and Fish Physiology, $2^{\text {nd }}$ ed, pp 125-140, CRC Lewis Publishers, Boca Raton, FL.

Hille, B. (1992): Ionic channels of excitable membranes. $2^{\text {nd }}$ ed, Sinauer, Sunderland, MA.

Javed, M. (2013): Chronic Effects of Nickel and Cobalt on Fish Growth. International Journal of Agricultural Biology, 15, 575-579.

Javed, M., Saeed, M. A. (2010): Growth and bioaccumulation of iron in the body organs of Catla catla, Labeo rohita and C.rrhina mrigala during chronic exposures. International Journal of Agricultural Biology, 12, 881-886.

Jitarm, O., Teodosiu, C., Oros, A., Plavan, G., Nicoara, M. (2015): Bioaccumulation of heavy metals in marine organisms from the Romanian sector of the Black Sea. New Biotechnology, 32, 369-78.

John, P.J. (2007): Alteration of certain blood parameters of freshwater teleost Mystus viitatus after chronic exposure to Metasystox and Sevin. Fish Physiology and Biochemistry, 33, 15-20.

Khanna, S. S., Gill, T. S. (1975): Effect of cobalt salts on the glycemia and islet histology of Channa punctatus (Bloch). Acta Analatica, 92, 194.

Lan, W. G., Wang, M.K., Chen, N., Sin, Y. M. (1995): Effects of combined copper, zinc, chromium, and selenium by orthogonal array design on alkaline phosphatase activity in liver of the red sea bream, Chrysophrys major. Aquatics, 131, 219-230.

Lévesque, H. M., Dorval, J., Van der kraak, G. J., Campbell, P. G. C., Hontela, A. (2003): Hormonal, morphological and physiological responses of yellow perch (Perca flavescens) to chronic environmental metal exposures. Journal of Toxicological Environment, 66, 87-106.

Ln, K. N., Vosylienë, M.Z. (1999): Peculiarities of the physiological responses of rainbow trout to copper. Acta Zoological Lituania Hydrobiology, 9, 1392-1657.

Luskova, V. (1997): Annual cycles and normal values of hematological parameters in fishes. Acta Sciantiarum Naturalium, 31, 70.

Marra, J. C. A., Hansenb, et al. (1998): Toxicity of cobalt and copper to rainbow trout: application of a mechanistic model for predicting survival. Aquatic Toxicology, 43, 4, 225-238.

Mukherjee, S., Kaviraj, A. (2009): Evaluation of growth and bioaccumulation of cobalt in different tissues or common carp, Cyprinus carpio (Actinopterygii Cypriniformes: Cyprinidae), fed cobalt-supplemented diets. Acta Ichthyological Piscator, 39, 87-93.

Mutlu, E., Aydın, S., Kutlu, B. (2015): Alterations of growth performance and blood chemistry in Nile tilapia (Oreochromis niloticus) affected by copper sulfate in long-term exposure. Turkish Journal of Fish and Aquatic
Science, 15, 481-488.

Oner, M., Atli, G., Canli, M. (2008): Changes in serum biochemical parameters of freshwater fish Oreochromis niloticus following prolonged metal $(\mathrm{Ag}, \mathrm{Cd}, \mathrm{Cr}, \mathrm{Cu}, \mathrm{Zn})$ exposures. Environmental Toxicological Chemistry, 27, 360-366.

Pedlar, R. M., Ptashynski, M. D., Wautier, K. G., Evans, R. E., Baronb, C. L., Laverkamp, J. F. (2002b): The accumulation, distribution, and toxicological effects of dietary arsenic exposure in lake white fish (Coregonus clupeaformis) and lake trout (Salvelinus namaycush). Comparative Biochemistry and Physiology Part C, 131, 73-91.

Pratap, H. B., Wendelaar Bonga, S. E. (1990): Effect of waterborne cadmium on plasma cortisol and glucose in the cichlid fish Oreochromis mossambicus. Comparative Biochemistry and Physiology, 95, 313-317.

Saeed, S. M. (2000): A study on factors affecting fish production from certain fish farms in the delta. MSc Thesis, Ain Shames University, Egypt.

Tuncsoya, M., Durana, S., Yesilbudaka, B., Ayb, O., Cicikb, B., Erdem, C. (2016): Shortterm effects of zinc on some sera biochemical parameters and tissue accumulation of Clarias gariepinus. Fresenius Environmental Bulletin, 2, 658-664.

Ubaid-ullah, M., Javed, M., Abdullah, S. (2004): Impact of waste disposal on the uptake and accumulation of heavy metals in the planktonic biomass of the river Ravi. International Journal of Agricultural Biology, 6, 629-63.

Vinodhini, R., Narayanan, M. (2008): Bioaccumulation of heavy metals in organs of fresh water fish Cyprinus carpio (Common carp). International Journal of Environmental Science and Technology, 5, 179-182.

Waiwood K. G., Beamish, F. W. H. (1978): The effects of copper, hardness and $\mathrm{pH}$ on the growth of rainbow trout, Salmo gairdneri. J Fish Biol 1978, 13:591-598.

Watanabe, T., Kiron, V., Satoh, S. (1997): Trace minerals in fish nutrition. Aquaculture, 151, 185-207.

Weatherley, A. H, Cill, H. S. (1987): The Biology of Fish Growth, Academic Press, New York.

Wong, C. K. C., Yeung, H. Y., Woo, P. S., Wong, M. H. (2001): Specific expression of cytochrome P4501A1 gene in gill, intestine and liver of tilapia exposed to coastal sediments. Aquatic Toxicology, 54, 69-80.

Yamatani, K., Saito K. et al. (1998): Relative contribution of $\mathrm{Ca}^{+}$dependent mechanism in glucagon-induced glucose output from the liver. Arch. Biochem Biophy. 355, 175-180.

Yan, J. L., Chen, H. C. (2003): Serum metabolic enzyme activities and hepatocyte ultrastructure of common carp after gallium exposure. Zoological Studies, 42, 455-461.

Younis, E. M., Abdel-Warith, A. A., Al-Asgah, N. A. (2012): Hematological and enzymatic responses, of Nile tilapia Oreochromis niloticus during short and long term sublethal exposure to zinc. African Journal of 
Biotechnology, 11, 4442-4446.

Zheng, L. L., Yuan, S. S., Wu, C.W., Li, W. Y. (2016): Chronic waterborne zinc and cadmium exposures induced different responses towards oxidative stress in the liver of zebrafish. Aquatic Toxicology, 177, 261-268.

Zhiteneva, L. D., Poltavceva, T.G., Rudnickaja, O. A. (1989): Atlas of normal and pathological cells in the blood of fish. Rostovon-Don, 112.
Zikić, R.V., Stajn, A.S., Pavlović, S. Z., Ognjanović, B. I., Saičić, Z. S. (2001): Activities of superoxide dismutase .and catalase in erythrocytes and plasma transaminases of goldfish (Carassius auratus gibelio Bloch.) exposed to cadmium. Physiological Research, 50, 105-111. 